\title{
An investigation into responsible tourism practices in the South African hotel industry
}

\author{
M. v.d. Merwe and A. Wöcke* \\ Gordon Institute of Business Science, University of Pretoria, \\ PO Box 787602, Sandton 2146, Republic of South Africa \\ wockea@gibs.co.za
}

Received November 2006

\begin{abstract}
This paper sheds light on the reasons for the limited uptake of responsible tourism initiative memberships by hotels in South Africa, despite South Africa being regarded as a leader in the field of responsible tourism policy, with the drafting of responsible tourism guidelines by the South African Department of Environmental Affairs and Tourism (DEAT). The International Centre for Responsible Tourism's conference (hosted in South Africa) preceding the World Summit on Sustainable Development in 2002 resulted in the Cape Town Declaration, which was based on the guidelines developed by DEAT. There are currently two responsible tourism membership initiatives in South Africa. Non-experimental survey research was conducted among hotels about their understanding and implementation of responsible tourism practices. Sixty hotels responded to the survey, and it would appear that these hotels implement Corporate Social Responsibility/responsible tourism, though to varying extents. Many responding hotels do not participate in responsible tourism initiatives because of - amongst others - confusion about what the concept means, and a lack of awareness of such initiatives. This paper raises questions about the effectiveness of membership initiatives in promoting the implementation of responsible tourism practices and questions the importance of a common understanding and awareness of what responsible tourism entails in ensuring that policy is implemented.
\end{abstract}

*To whom all correspondence should be addressed.

\section{Introduction}

South Africa is faced with widespread unemployment and poverty and it is widely believed that the tourism industry can make a significant contribution to addressing these problems (e.g. Ashley, Roe \& Goodwin, 2001). Tourism is seen as a high-impact industry on the environment within which it operates and is regarded as the largest industry worldwide (World Travel and Tourism Council (WTTC), IFTO, IH\&RA, ICCL \& UNEP, 2002). The importance of responsible tourism was highlighted at the Earth Summit in Rio de Janeiro in 1992 with Agenda 21 and the Rio Declaration, which articulated the main principles for sustainable development in the $21^{\text {st }}$ century (WTTC et al., 2002). A comprehensive and useful definition of the term responsible tourism is that of the South African Department of Environmental Affairs and Tourism (DEAT), which defines the term as 'tourism that promotes responsibility to the environment through its sustainable use; responsibility to involve local communities in the tourism industry; responsibility for the safety and security of visitors and responsible government, employees, employers, unions and local communities' (DEAT, 1996:4).

Despite the global focus on the tourism industry as part of the sustainability agenda at World Summit on Sustainable Development (WSSD), there seem to be very few tourism companies participating in globally responsible tourism or Corporate Social Responsibility (CSR) initiatives such as the Global Compact (tourism companies only represent $2 \%$ of all companies participating in the voluntary initiative). Research amongst UK-based tour operators (Gordon, 2001) found that these tourism companies have been very slow in implementing socially responsible tourism principles in their businesses and there is little evidence that South Africa is different.

\section{Aims and contribution of the study}

This study aims to shed light on the reasons South African hotels adopt or ignore CSR/responsible tourism initiatives, despite government policy and a growing global awareness of the concept. We are guided by the following research questions:

- What is the extent of CSR/responsible tourism in the South African hotel industry?

- What is the understanding of the concepts of $\mathrm{CSR} /$ responsible tourism in the industry?

- Do government policy and membership of tourism bodies promote or advance the adoption of CSR/responsible tourism practices?

- Is the business rationale for the adoption of CSR/responsible tourism well understood by the South African hotel industry? 
- How important is membership of tourism bodies to the promotion of CSR/responsible tourism?

A deeper understanding of the nature of CSR/responsible tourism practices by the South African hotel industry and an understanding of the role of government and tourism bodies in the South African hotel industry will support policy and private sector initiatives to expand and entrench responsible tourism practices in South Africa. Additionally the study will fill an important gap in the literature on the motives of hotels in adopting CSR and guide further research in this vital area of the economy.

\section{The South African hotel industry}

The accommodation sector forms a significant part of the tourism industry in South Africa and can be regarded as integral to any tourism initiative. This study focuses on hotels only as they are the most developed sub-sector of the accommodation sector and as a result are the most organised sector in the industry. This study included all hotels in all the provinces of South Africa. A hotel is defined by the Tourism Grading Council of South Africa (TGCSA) as an establishment that 'provides accommodation to the travelling public, has a reception area and offers at least a 'breakfast room' or communal eating area' (TGCSA, 2002). In total, there are approximately 11,000 accommodation establishments, including hotels, self-catering establishments, game lodges, guest-houses, bed and breakfast establishments in South Africa. Of these, about 1,000 are hotels. The majority of hotels are located in urban centres such as Cape Town, Johannesburg, Durban and Pretoria (Grant Thornton, 2005). There are 12 companies listed as 'leisure and hotels' companies on the JSE (JSE, 2005b). These companies represent approximately 65 hotels (or 6,5\% of the South African hotel industry). Other hotels operate as private entities. Hotels vary in size and on average hotels in South Africa have 60 rooms (Grant Thornton, 2004).

\section{Responsible tourism and corporate responsibility}

Core to the concept of responsible tourism is the concept of Corporate Social Responsibility (CSR), which is defined as '...a commitment to improve community well-being through discretionary business practices and contributions of corporate resources' (Kotler \& Lee, 2005:3). Others simply describe it as being how business takes into account the economic, social and environmental impact of the way it does business (Carrol, 1979; Garriga \& Mele, 2004; Cannife, 2005). These are elaborated on in the Global Compact (2005a) of the United Nations as 10 principles broadly categorised as compliance and respect for human rights, labour standards, the environment, and anticorruption. There is also a wealth of terminology in the field, all referring more or less to the same concept although with differing areas of emphasis (Votaw \& Sethi, 1973; Valor, 2005). An example of this is the pro-poor tourism (PPT) initiative, which is defined as interventions that aim to increase the net benefits for the poor from tourism and ensuring that tourism growth contributes to poverty reduction (Ashley et al., 2001). Ashley and Haysom (2005) link the CSR debate to PPT in South Africa, by highlighting the need for businesses to move from philanthropic donations to changing their business practices in an encompassing corporate citizenship model.

Logsdon and Wood (2002) argue that CSR was developed in the early 1960's to shift power from corporations to society, based on moral ideas about human rights taking precedence over corporate rights. A related concept, Corporate Citizenship (CC), reflects businesses as being 'good citizens' by doing good in their communities. CSR is a more robust concept than Corporate Citizenship, however it is acknowledged that both CSR and CC are concepts that 'exist to guard against the undesirable consequences of power imbalances in social structures' (Logsdon \& Wood, 2002:179).

According to Van Marrewijk (2003) there are three approaches to the concept of CSR. The first of these is a shareholder approach, based on Milton Friedman's view that 'the only one responsibility of business towards society is the maximization of profits to the shareholders within the legal framework and the ethical custom of the country' (Friedman, 1970, cited in Garriga \& Melé, 2004:53). In the 1980's, the stakeholder approach was popularised by Freeman (1984, cited in Van Marrewijk, 2003), and it assumes that business has a responsibility to all of its stakeholders and not just its shareholders. Freeman (1984, cited in Valor, 2005) refers to stakeholders as all groups or individuals who could influence or are influenced by the outcome of a company's objectives. The most recent approach is the societal approach, which assumes that business is responsible to the society within which it operates (Van Marrewijk, 2003). Van Marrewijk (2003) further suggests that CSR and corporate sustainability can be regarded as synonyms, and concludes that the concepts can broadly be defined as 'company activities - voluntary by definition - demonstrating the inclusion of social and environmental concerns in business operations and in interactions with stakeholders' (Van Marrewijk, 2003:102).

Garriga and Melé (2004) felt the need to consolidate the theories in the field. They based their consolidation on the hypothesis that all relevant CSR theories and approaches are focused on either politics, economics, social integration or ethics, and have subsequently grouped together theories in four categories, i.e. instrumental theories (similar to Van Marrewijk's shareholder approach), political theories (stakeholder approach), integrative theories (stakeholder and societal approach) and ethical theories (reflecting the societal approach). Instrumental theories understand CSR as a means to achieve profits, while political theories emphasise the social power of corporations. Integrative theories promote the integration of societal demands because the corporation is dependent on society for its existence, and finally ethical theories are based on the understanding that the relationship between society and business is founded in ethical values. Garriga and Melé (2004) conclude that most current theories on CSR focus on: meeting objectives that produce long-term profits; using business power in a responsible way; integrating social demands; and contributing to a good society by doing what is ethically correct. Locke (2003) provides another variation 
on the combination of theories, and groups the theories as minimalist (Friedman), philanthropic (not related to core business activities), encompassing (Freeman's stakeholder view) and the social activist model of extending benefits to the broader society.

However, there are also critics of CSR, such as Henderson (2005), who believes, as Friedman did (1970), that the business of business is to make profits, by concluding that 'the case for private business has always rested, and still rests, on the links between private ownership, competition and economic freedom within a market-directed economy' (Henderson, 2005:32). In fact, Henderson believes that implementing CSR could result in increased costs and lower profits for businesses.

These concepts, while laudable and generally accepted, are difficult to define in operational terms, especially for small businesses, which make up the majority of the South African tourism industry. A small number of listed hotel groups in South Africa provide information about their CSR activities in their annual reports (City Lodge, 2004; Sun International, 2003), while the Southern Sun group (not a listed company) publishes a 'Corporate Citizenship and Sustainability Report (Southern Sun, 2002) on their website. The City Lodge group is also included in the socially responsible investment index of the JSE. One of the reasons for the limited information on CSR/responsible tourism activites in the industry may be confusion over the conceptualisation and operationalisation of the concepts of Responsible Tourism and Corporate Social Responsibility.

\section{Government and industry association initiatives}

There are a number of responsible tourism initiatives in South Africa in the form of voluntary guidelines, certification membership organisations and responsible tourism awards and the concept is entrenched in the White Paper on the Development and Promotion of Tourism in South Africa (1996). Additionally the DEAT has developed guidelines for responsible tourism in South Africa during 2002, which was published as a 'responsible tourism handbook' in 2003 (DEAT, 2003). Further, the Federated Hospitality Association of Southern Africa launched the Imvelo responsible tourism awards in 2002 (Fedhasa, 2005) to encourage tourism businesses to comply with the DEAT responsible tourism guidelines.

A similar initiative established by the International Union for the Conservation of Nature and Natural Resources (IUCN) in 2002 certifies applicants with the 'Fair Trade in Tourism South Africa (FTTSA) Trademark' (FTTSA, 2005a). It follows the establishment of an international network on fair trade in tourism by London-based Tourism Concern (FTTSA, 2005b). The requirements for an organisation to obtain the right to use the FTTSA trademark are very strict, and a number of applicants have been turned down since its inception (Bac, 2005). FTTSA currently has 14 certified trademark users, the majority (8) being hotels.

Similarly the Heritage Environmental Ratings Programme (Heritage, 2005) recently launched a responsible tourism guide which lists its members. Heritage is an independent ratings programme that audits its members on an 8-monthly basis (McManus, 2005). It is based on international best practice, and rates its members according to different categories, according to the member's level of compliance with the certification requirements. It is an ISO 14000 compatible ratings system. There are currently 33 South African members of the programme - of which 27 are hotels. There are some South African tourism companies that are internationally recognised for their efforts in the field of responsible tourism, such as Wilderness Safaris - a well-known operator of safari lodges in Southern Africa. One of their operations in Namibia recently won the conservation award in the WTTC's Tourism for Tomorrow Awards (WTTC, 2005a). Wilderness Safaris' operations were further included in PPT pilot programmes in South Africa (Ashley \& Haysom, 2005), together with the internationally renowned Spier in Stellenbosch, CC Africa lodges in Mpumalanga and northern KwaZulu-Natal and Sun City. These companies were also used as some of the examples of good practice in DEAT's Responsible Tourism Guidelines (2003).

Despite these many government and industry initiatives, few tourism companies participate in these initiatives, though the tourism industry is regarded as the largest contributor to global GDP (WTTC, 2005b). In 2006, globally this is expected to create US $\$ 6,477.2$ billion of economic activity, $10.3 \%$ of the global GDP and $234,305,000$ jobs or $8.7 \%$ of total global employment (WTTC, 2006).

These initiatives are voluntary and there is no real incentive to participate in CSR/responsible tourism activities as a result. It is significant that the most of the tourism companies that actively participate in CSR initiatives are either listed on the JSE or members of (voluntary) organisations that promote responsible tourism (FTTSA, 2005b; FEDHASA, 2005; Heritage, 2005; JSE 2005a; WTTC, 2005a).

\section{The business rationale for participation in responsible tourism and corporate Social Responsibility}

The social and political changes in South Africa since the early 1990's have forced business to fully embrace a value system of good corporate citizenship (Rockey, 2001). In recognition of this, the Johannesburg Stock Exchange has recently launched a socially responsible investment index (De Cleene \& Sonnenburg, 2004) and the University of South Africa has opened a Centre for Corporate Citizenship at its College for Economic and Management Sciences. Bowes and Pennington (2005), argue that corporate social responsibility is an increasingly important aspect of doing business in South Africa, and that most companies view it as a strategic tool that can be used to improve the lives of South Africans in general. CSR has been recognised as a strategic business imperative that can lead to benefits such as cost savings (Birch \& Littlewood, 2004; McManus, 2005) as well as being regarded as one of the seven pillars of good corporate governance (Lashinger, 2004).

The hotel industry's response to the sustainable development challenge has resulted in hotels developing 
voluntary environmental management systems, educational initiatives, initiatives such as eco-labelling, multistakeholder communication and consultation, reporting and implementation of the Rio principles (WTTC et al., 2002). In 2001, Tearfund conducted research among UK-based tour operators to determine their views about ethical tourism in relation to bringing benefits to the local community, charitable giving, partnerships and responsible tourism policies. The findings of this study suggest that there are a number of good practice examples to be found, though they are sometimes hidden, which makes it difficult for tourists to make the positive choice. Gordon (2001) contends that tourists (in other words, the market) are more actively looking for a responsible experience and are no longer satisfied with policies that are in place but not implemented.

\section{Research methodology}

This study uses a quantitative methodology to test the reasons for the low level of support for responsible tourism initiatives in the hotel industry. A self-completion questionnaire was developed which was sent to respondents via e-mail; the questionnaire is appended to the study. To facilitate the ease of completing the questionnaire, respondents were provided with a number of possible answers for each question, based on information gathered during the literature review. An attempt was made to include all possible options, but respondents were provided with an option "other" that they could use to indicate a response that was not included in the list. Introductory questions obtained demographic information about the company while other questions provided a wide variety of meanings for the term CSR in order to test respondents' understanding of the concept. Question 5 of the questionnaire related to DEAT's responsible tourism guidelines, while Question 6 attempted to solicit specific information about the respondent's reason for implementing the various elements. The final three questions verified whether the respondent was a member of either of the two hotel industry membership organisations that promote responsible tourism (FTTSA and Heritage) and whether or not they had participated in the Responsible Tourism Awards.

\section{Population and sample}

The population of reference for this study is all hotels in the nine South African provinces. The sample included both hotels that report on the implementation of CSR/responsible tourism principles in their operations (for example, members of certification programmes) and those that don't. The main sampling method used during this research study was convenience sampling where hotels were selected from a variety of hotel databases. The databases included in the sample were:
- Tourism Grading Council hotels listing (TGCSA, 2005)

- $\quad$ Protea Hotels (Protea Hotels, 2005)

- The Don Group (The Don Group, 2005)

- Tshwane Accommodation listing (Tshwane Tourism Plan, 2005)

- $\quad$ Tourism KwaZulu-Natal hotels listing (TKZN, 2002)

The above sampling technique resulted in 600 hotels being included in the sample, which represents approximately $60 \%$ of the total population of registered hotels in South Africa. A total of 60 responses were received, indicating a response rate of $10 \%$, which was deemed an acceptable sample. Of these, 15 - or $25 \%$ of the respondents - were either members of FTTSA or Heritage, indicating a response rate of $43 \%$ among members of these organisations. Responding hotels varied in size. Sizes ranged from a small, boutique hotel with 6 rooms, to a large hotel with 318 rooms. The average size was 67 rooms and 73 employees. The demographics of the sample are illustrated in table 1 below. Table 2 contains the results of a $t$-test of the sample means, members and non-members. Although both samples have a similar geographic spread and are similar types of legal entity, large differences are evident in the size of the hotels, both in terms of rooms and numbers of employees. Members had on average 100 rooms and 153 employees, while non-members had 57 rooms and 46 employees.

\section{Respondents}

It was expected that information about the reasons for participating or not participating in CSR/responsible tourism initiatives for a particular hotel would not be readily available to all employees. The majority of questionnaires (48 or $80 \%$ ) were completed by either the general manager, owner or managing director of the hotel in question. In some cases the person completing the questionnaire held a position related to CSR/responsible tourism. All questionnaires were completed by respondents in management positions, or by someone able to gain access to the general manager for information.

\section{Data analysis}

The primary method used to analyse the nominal data collected during the research study was frequency analysis. This study does not attempt to prove correlation or causality between variables, and therefore frequency analysis is adequate for the purposes of answering the propositions. 
Table 1: Statistics of the sample

\begin{tabular}{|c|c|c|c|c|c|}
\hline & Membership * & $\mathbf{N}$ & Mean & Std. Deviation & $\begin{array}{c}\text { Std. Error } \\
\text { Mean }\end{array}$ \\
\hline \multirow[t]{2}{*}{ Location } & 1 & 15 & 3,93 & 2,685 & ,693 \\
\hline & 2 & 45 & 5,51 & 2,546 & ,380 \\
\hline \multirow[t]{2}{*}{ \# rooms } & 1 & 15 & 99,60 & 92,525 & 23,890 \\
\hline & 2 & 45 & 56,69 & 44,479 & 6,631 \\
\hline \multirow[t]{2}{*}{ \# Employees } & 1 & 15 & 152,73 & 115,909 & 29,927 \\
\hline & 2 & 45 & 45,04 & 48,268 & 7,195 \\
\hline \multirow[t]{2}{*}{ Level of Service } & 1 & 15 & 1,00 &, 000 &, 000 \\
\hline & 2 & 45 & 1,31 & ,514 & ,077 \\
\hline \multirow[t]{2}{*}{ Type of Legal Entity } & 1 & 15 & 2,07 & 1,033 & ,267 \\
\hline & 2 & 45 & 2,36 & 1,026 & ,153 \\
\hline
\end{tabular}

(*Membership: 1- member of industry body, 2- not a member of industry body)

Table 2: Independent samples test

\begin{tabular}{|c|c|c|c|c|c|c|c|c|}
\hline & & \multicolumn{7}{|c|}{ t-test for Equality of Means } \\
\hline & & \multirow[t]{2}{*}{ t } & \multirow[t]{2}{*}{ df } & \multirow[t]{2}{*}{$\begin{array}{l}\text { Sig. (2- } \\
\text { tailed) }\end{array}$} & \multirow[t]{2}{*}{$\begin{array}{c}\text { Mean } \\
\text { Difference }\end{array}$} & \multirow[t]{2}{*}{$\begin{array}{l}\text { Std. Error } \\
\text { Difference }\end{array}$} & \multicolumn{2}{|c|}{$\begin{array}{l}\text { 95\% Confidence Interval } \\
\text { of the Differences }\end{array}$} \\
\hline & & & & & & & Lower & Upper \\
\hline \multirow[t]{2}{*}{ Location } & $\begin{array}{l}\text { Equal } \\
\text { variances } \\
\text { assumed }\end{array}$ & $-2,051$ & 58 & ,045 & $-1,578$ & ,769 & $-3,118$ &,- 038 \\
\hline & $\begin{array}{l}\text { Equal } \\
\text { variances } \\
\text { not assumed }\end{array}$ & $-1,996$ & 22,993 & ,058 & $-1,578$ & ,790 & $-3,213$ & ,057 \\
\hline \multirow[t]{2}{*}{ \# rooms } & $\begin{array}{l}\text { Equal } \\
\text { variances } \\
\text { assumed } \\
\end{array}$ & 2,410 & 58 & ,019 & 42,911 & 17,807 & 7,266 & 78,556 \\
\hline & $\begin{array}{l}\text { Equal } \\
\text { variances } \\
\text { not assumed }\end{array}$ & 1,731 & 16,209 & 102 & 42,911 & 24,793 & $-9,592$ & 95,415 \\
\hline \multirow[t]{2}{*}{ \# Employees } & $\begin{array}{l}\text { Equal } \\
\text { variances } \\
\text { assumed }\end{array}$ & 5,103 & 58 & ,000 & 107,689 & 21,104 & 65,445 & 149,932 \\
\hline & $\begin{array}{l}\text { Equal } \\
\text { variances } \\
\text { not assumed }\end{array}$ & 3,499 & 15,649 & ,003 & 107,689 & 30,780 & 42,318 & 173,059 \\
\hline \multirow[t]{2}{*}{$\begin{array}{l}\text { Level of } \\
\text { Service }\end{array}$} & $\begin{array}{l}\text { Equal } \\
\text { variances } \\
\text { assumed } \\
\end{array}$ & $-2,329$ & 58 & ,023 &,- 311 & ,134 &,- 579 &,- 044 \\
\hline & $\begin{array}{l}\text { Equal } \\
\text { variances } \\
\text { not assumed }\end{array}$ & $-4,057$ & 44,000 & ,000 &,- 311 & ,077 &,- 466 &,- 157 \\
\hline \multirow[t]{2}{*}{$\begin{array}{l}\text { Type of } \\
\text { Legal Entity }\end{array}$} & $\begin{array}{l}\text { Equal } \\
\text { variances } \\
\text { assumed } \\
\end{array}$ &,- 943 & 58 & ,350 &,- 289 & ,306 &,- 902 & ,324 \\
\hline & $\begin{array}{l}\text { Equal } \\
\text { variances } \\
\text { not assumed }\end{array}$ &,- 940 & 23,901 & ,357 &,- 289 & ,307 &,- 923 & ,346 \\
\hline
\end{tabular}




\section{Limitations}

There were several limitations to the study that may have had an influence on the results, these are:

- As a result of the databases used, there was a bias towards graded hotels, however the sample represented approximately $60 \%$ of all hotels in South Africa.

- Hotels were contacted via e-mail and those without email were excluded as a result. This should not be a confounding factor as the sample includes hotels small and large hotels and also independent and affiliated hotels.

- Some e-mail addresses were incorrectly listed, resulting in a number of e-mails not reaching the relevant hotels. However, this was limited to no more than $3 \%$ of the sample.

\section{Results and findings}

Extent to which Responsible Tourism Practices are implemented

To gauge whether respondents implemented any form of CSR, they were provided with the Department of Environmental Affairs and Tourism's Responsible Tourism guidelines and then asked whether their company implemented any of the guidelines. From their responses it appeared that very few do not implement at least some form of CSR / responsible tourism, though the degree to which they implement it varies (Table 2).

Of the six economic elements and three environmental elements, responding hotels implemented on average $47 \%$ of the six elements, followed by $45 \%$ of the four social elements and $40 \%$ of the six elements to motivate guests to be responsible. The highest percentage of responding hotels did not implement any of the general elements, which include things like setting targets for being responsible, working with trade associations to achieve objectives and using responsible tourism as part of their marketing strategy. Members of tourism bodies/associations implement on average a higher number of responsible tourism elements than non-members as shown in table 3 below.

\section{Understanding of the Concepts of Corporate Social} Responsibility and Responsible Tourism

Respondents were asked to indicate what the term CSR means to them in an attempt to determine the level of understanding of the concept. They could choose any number of descriptions from the list provided, and there was also an option to provide additional information in writing. Table 4 provides the number of responses per description provided. More than $95 \%$ of respondents indicated that they understand CSR to be a responsibility towards the community within which they operate their business. Other descriptions selected by more than $50 \%$ of respondents include 'future sustainability of the industry', 'protecting the environment' and 'ethical business practices'. Only nine respondents selected one description for CSR, while one respondent selected 12 of the 13 possible descriptions. The average number of descriptions per respondent is 4,8 with members selecting on average 3,8 descriptions, while nonmembers selected 5,2, which may indicate that the two associations are quite clear about their definitions of CSR and responsible tourism and it follows that clarity of the concept would be one of the benefits of belonging to the respective associations.

\section{Government and Industry Requirement as a Driver of Corporate Social Responsibility}

We wanted to explore the impact that government policy and membership of tourism bodies that encouraged CSR/responsible tourism would have on the adoption of these practices by hotels. There are nine public companies among responding hotels, two of which are members. 18 hotels did not implement responsible tourism practices while $43 \mathrm{did}$. A measure of participation is the degree to which CSR and responsible tourism activities are reflected in marketing materials or reported elsewhere. Only two responding hotels - both non-members - indicated that they do not include their CSR/responsible tourism practices in their marketing and/or communications because it is not required by law. A total of six respondents indicated that they implement responsible tourism elements in their business because it is required by their membership organisation, either FTTSA or Heritage. Only four respondents did so because they perceived it to be a legal or government requirement. When asked about reasons for not including their responsible tourism policy in their marketing material, an indicator of level of importance associated with it, the majority of responding hotels stated that they did not believe it was important (50\%) while a further $28 \%$ stated that they had not thought about it. This is reflected in table 5 below and shows clearly that hotels in the South African tourism industry do not participate in responsible tourism and CSR initiatives because there are no legal or industry regulations requiring them to.

\section{Business Rationale for Participation in CSR Responsible Tourism}

The business rationale of CSR/responsible tourism practices would specifically relate to profitability (including cost saving), marketing, and sustainability of the industry. Strategic issues were not descriptions that most respondents used to describe CSR, yet these descriptions were chosen by a significant number of respondents. The 'future sustainability of the industry' is the business issue chosen by the largest number of respondents.

Respondents were asked to provide reasons - they could provide any number of reasons from a list, as well as add additional reasons - for implementing the guidelines. Responding hotels provided on average four reasons for implementing the guidelines. Most of the responding hotels implement the guidelines because it 'improves relationships with the community where I operate my business' and because it 'protects the environment'. Also because it 'is the ethical / the right thing to do' and for 'the future sustainability of the industry'. 
Table 6 illustrates the extent to which responsible tourism guideline elements are implemented by responding hotels. The table is arranged by most frequent to least frequent guidelines.

Respondents were then asked for reasons CSR/responsible tourism practices were implemented. The results are shown in table 7 below.

Those responding hotels with responsible tourism policies were then asked whether they include these policies in their marketing material and/or communications, to which 25 (or $58 \%$ of responding hotels with responsible tourism policies) responded yes. Almost 92\% of members with responsible tourism policies include these policies in their marketing material and/or communications, while only $45 \%$ of nonmembers do so. Respondents were further asked where they included these policies, the results of which are indicated in Table 8 .

Table 3: Implementation of responsible tourism guideline elements

\begin{tabular}{|c|c|c|c|c|c|c|}
\hline \multirow[b]{2}{*}{$\begin{array}{c}\text { Guideline Element } \\
\text { Category }\end{array}$} & \multicolumn{2}{|c|}{ All Responding Hotels } & \multicolumn{2}{|c|}{ Members } & \multicolumn{2}{|c|}{ Non-Members } \\
\hline & $\begin{array}{c}\text { Average \% of } \\
\text { Elements } \\
\text { Implemented }\end{array}$ & $\begin{array}{c}\text { \# of } \\
\text { Responding } \\
\text { hotels that did } \\
\text { not implement } \\
\text { any elements }\end{array}$ & $\begin{array}{l}\text { Average \% of } \\
\text { Elements } \\
\text { Implemented }\end{array}$ & $\begin{array}{l}\text { \# of Members } \\
\text { that did not } \\
\text { implement } \\
\text { any elements }\end{array}$ & $\begin{array}{c}\text { Average \% of } \\
\text { Elements } \\
\text { Implemented }\end{array}$ & $\begin{array}{c}\text { \# of Non- } \\
\text { Members that } \\
\text { did not } \\
\text { implement any } \\
\text { elements }\end{array}$ \\
\hline Economic & $47 \%$ & 16 & $58 \%$ & 3 & $43 \%$ & 13 \\
\hline Social & $45 \%$ & 17 & $58 \%$ & & $40 \%$ & 14 \\
\hline Environmental & $47 \%$ & 21 & $67 \%$ & 3 & $41 \%$ & 18 \\
\hline $\begin{array}{l}\text { Motivating Guests } \\
\text { to be Responsible }\end{array}$ & $40 \%$ & 16 & $40 \%$ & 3 & $40 \%$ & 13 \\
\hline General & $36 \%$ & 27 & $60 \%$ & 3 & $28 \%$ & 24 \\
\hline TOTAL & $43 \%$ & 13 & $55 \%$ & 3 & $39 \%$ & 10 \\
\hline $\mathbf{N}$ & & 60 & & 15 & & 45 \\
\hline
\end{tabular}

Table 4: Responses to definitions of corporate social responsibility

\begin{tabular}{|c|c|c|c|}
\hline Description & $\begin{array}{l}\text { All Respondents } \\
\%\end{array}$ & $\begin{array}{c}\text { Members } \\
\%\end{array}$ & $\begin{array}{l}\text { Non-Members } \\
\%\end{array}$ \\
\hline $\begin{array}{l}\text { responsibility to the community within which I operate my } \\
\text { business }\end{array}$ & $96,7 \%$ & $86,7 \%$ & $100 \%$ \\
\hline ethical business practices & $65,0 \%$ & $60 \%$ & $66,7 \%$ \\
\hline protecting the environment & $63,3 \%$ & $60 \%$ & $64,4 \%$ \\
\hline future sustainability of the industry & $58,3 \%$ & $53,3 \%$ & $60 \%$ \\
\hline feel-good factor & $38,3 \%$ & $33,3 \%$ & $40 \%$ \\
\hline legal compliance & $35,0 \%$ & $46,7 \%$ & $31,1 \%$ \\
\hline marketing opportunity & $33,3 \%$ & $6,7 \%$ & $42,2 \%$ \\
\hline increased profitability & $20,0 \%$ & $6,7 \%$ & $24,4 \%$ \\
\hline strategic business tool & $20,0 \%$ & $6,7 \%$ & $24,4 \%$ \\
\hline philanthropic donations & $18,3 \%$ & $6,7 \%$ & $22,2 \%$ \\
\hline triple bottom line & $11,7 \%$ & $6,7 \%$ & $13,3 \%$ \\
\hline license to operate & $11,7 \%$ & $6,7 \%$ & $13,3 \%$ \\
\hline increased cost of doing business & $6,7 \%$ & $0 \%$ & $8,9 \%$ \\
\hline Other & $3,3 \%$ & $0 \%$ & $4,4 \%$ \\
\hline
\end{tabular}

Table 5: Reasons respondents do not include information about their responsible tourism policy in their marketing material

Reasons $\%$ of All Responding Hotels

\begin{tabular}{l|r}
\hline Don't believe it's important & $50 \%$ \\
\hline Haven't thought about it & $28 \%$ \\
\hline Not required by law & $6 \%$ \\
\hline Other: & $11 \%$ \\
\hline Is good practice, but do not need recognition for it & $6 \%$ \\
\hline It is an internal matter & $6 \%$ \\
\hline No Response & $6 \%$ \\
\hline TOTAL & $\mathbf{1 0 0 \%}$ \\
\hline
\end{tabular}


Table 6: Responsible tourism guidelines implemented

\begin{tabular}{|c|c|c|c|c|}
\hline Guideline & Category & $\begin{array}{c}\% \text { of All } \\
\text { Responding Hotels } \\
\end{array}$ & $\%$ of Members & $\begin{array}{l}\text { \% of Non- } \\
\text { Members }\end{array}$ \\
\hline Respect social and cultural diversity & Social & $70,0 \%$ & $80,0 \%$ & $66,7 \%$ \\
\hline $\begin{array}{l}\text { Employ responsible and transparent } \\
\text { processes when employing staff and pay } \\
\text { fair wages }\end{array}$ & Economic & $63,3 \%$ & $66,7 \%$ & $62,2 \%$ \\
\hline $\begin{array}{l}\text { Use natural resources in a sustainable } \\
\text { manner }\end{array}$ & Environmental & $60,0 \%$ & $73,3 \%$ & $55,6 \%$ \\
\hline $\begin{array}{l}\text { Encourage guests to conserve water and } \\
\text { energy by providing information in their } \\
\text { rooms }\end{array}$ & Motivating Guests & $56,7 \%$ & $66,7 \%$ & $53,3 \%$ \\
\hline $\begin{array}{l}\text { Promote equitable business practices and } \\
\text { ask fair prices. }\end{array}$ & Economic & $53,3 \%$ & $53,3 \%$ & $53,3 \%$ \\
\hline $\begin{array}{l}\text { Encourage guests to spend money in the } \\
\text { local community }\end{array}$ & Motivating Guests & $53,3 \%$ & $46,7 \%$ & $55,6 \%$ \\
\hline $\begin{array}{l}\text { Ensure communities are involved in and } \\
\text { benefit from tourism }\end{array}$ & Economic & $51,7 \%$ & $66,7 \%$ & $46,7 \%$ \\
\hline Be sensitive to the host culture & Social & $51,7 \%$ & $53,3 \%$ & $51,1 \%$ \\
\hline $\begin{array}{l}\text { Assist with local marketing and product } \\
\text { development }\end{array}$ & Economic & $43,3 \%$ & $40,0 \%$ & $44,4 \%$ \\
\hline $\begin{array}{l}\text { Reduce environmental impacts when } \\
\text { developing tourism }\end{array}$ & Environmental & $43,3 \%$ & $66,7 \%$ & $35,6 \%$ \\
\hline $\begin{array}{l}\text { Provide an opportunity for guests to } \\
\text { contribute to a local charity / funding } \\
\text { initiative }\end{array}$ & Motivating Guests & $41,7 \%$ & $46,7 \%$ & $40,0 \%$ \\
\hline $\begin{array}{l}\text { Work with trade associations, local people } \\
\text { and government to achieve objectives }\end{array}$ & General & $40,0 \%$ & $66,7 \%$ & $31,1 \%$ \\
\hline $\begin{array}{l}\text { Inform guests on how to interact with the } \\
\text { local community }\end{array}$ & Motivating Guests & $38,3 \%$ & $40,0 \%$ & $37,8 \%$ \\
\hline Show progress to staff and clients & General & $38,3 \%$ & $66,7 \%$ & $28,9 \%$ \\
\hline $\begin{array}{l}\text { Set targets and objectives for being } \\
\text { responsible }\end{array}$ & General & $36,7 \%$ & $60,0 \%$ & $28,9 \%$ \\
\hline Maintain biodiversity & Environmental & $35,0 \%$ & $46,7 \%$ & $31,1 \%$ \\
\hline $\begin{array}{l}\text { Maximise local economic benefits by } \\
\text { increasing linkages and reducing leakages }\end{array}$ & Economic & $33,3 \%$ & $53,3 \%$ & $26,7 \%$ \\
\hline $\begin{array}{l}\text { Use benchmarks to measure and report on } \\
\text { progress }\end{array}$ & General & $31,7 \%$ & $53,3 \%$ & $24,4 \%$ \\
\hline $\begin{array}{l}\text { Assess the economic impacts of your } \\
\text { tourism activities }\end{array}$ & Economic & $30,0 \%$ & $40,0 \%$ & $26,7 \%$ \\
\hline $\begin{array}{l}\text { Assess social impacts of your tourism } \\
\text { activities }\end{array}$ & Social & $28,3 \%$ & $46,7 \%$ & $22,2 \%$ \\
\hline $\begin{array}{l}\text { Provide separate bins in guest rooms for } \\
\text { waste }\end{array}$ & Motivating Guests & $28,3 \%$ & $6,7 \%$ & $35,6 \%$ \\
\hline $\begin{array}{l}\text { Use responsible tourism as part of your } \\
\text { marketing strategy }\end{array}$ & General & $28,3 \%$ & $33,3 \%$ & $26,7 \%$ \\
\hline $\begin{array}{l}\text { Involve local communities in planning and } \\
\text { decision making }\end{array}$ & Social & $23,3 \%$ & $33,3 \%$ & $20,0 \%$ \\
\hline $\begin{array}{l}\text { Provide an opportunity for guests to } \\
\text { contribute to local conservation } \\
\text { programmes }\end{array}$ & Motivating Guests & $18,3 \%$ & $13,3 \%$ & $20,0 \%$ \\
\hline
\end{tabular}


Table 7: Reasons for Implementing Responsible Tourism Guidelines

\begin{tabular}{|c|c|c|c|}
\hline Reason & $\begin{array}{l}\text { \% of Responding } \\
\text { hotels }\end{array}$ & $\%$ of Members & $\begin{array}{l}\text { \% of Non- } \\
\text { Members }\end{array}$ \\
\hline $\begin{array}{l}\text { Improves relationships with the community where I operate my } \\
\text { business }\end{array}$ & $56,7 \%$ & $60 \%$ & $55,6 \%$ \\
\hline Protects the environment & $56,7 \%$ & $73,3 \%$ & $51,1 \%$ \\
\hline Is ethical / the right thing to do & $55,0 \%$ & $53,3 \%$ & $55,6 \%$ \\
\hline Future sustainability of the industry & $50,0 \%$ & $73,3 \%$ & $42,2 \%$ \\
\hline It is important to me personally & $45,0 \%$ & $40 \%$ & $46,7 \%$ \\
\hline Saves costs & $31,7 \%$ & $40 \%$ & $28,9 \%$ \\
\hline Is strategically important to my business & $28,3 \%$ & $20 \%$ & $31,1 \%$ \\
\hline Because of the feel-good factor & $28,3 \%$ & $26,7 \%$ & $28,9 \%$ \\
\hline No Response & $25,0 \%$ & $20 \%$ & $26,7 \%$ \\
\hline Influence from guests & $13,3 \%$ & $13,3 \%$ & $13,3 \%$ \\
\hline Influence from tour operators & $11,7 \%$ & $20 \%$ & $8,9 \%$ \\
\hline Required by membership organisation & $10,0 \%$ & $20 \%$ & $6,7 \%$ \\
\hline Required by law & $6,7 \%$ & $6,7 \%$ & $6,7 \%$ \\
\hline Able to charge a premium & $1,7 \%$ & $0 \%$ & $2,2 \%$ \\
\hline
\end{tabular}

Table 8: Where Responding Hotels Included their Responsible Tourism Policy

\begin{tabular}{|c|c|c|c|}
\hline Responsible tourism policy is included in: & $\begin{array}{c}\text { All Responding Hotels } \\
\%\end{array}$ & $\begin{array}{l}\text { Members } \\
\%\end{array}$ & $\begin{array}{c}\text { Non-Members } \\
\%\end{array}$ \\
\hline Website & $64 \%$ & $55 \%$ & $71 \%$ \\
\hline Brochures & $56 \%$ & $45 \%$ & $64 \%$ \\
\hline Advertisements & $56 \%$ & $64 \%$ & $50 \%$ \\
\hline Other: & $32 \%$ & $55 \%$ & $14 \%$ \\
\hline E-mail & $8 \%$ & $9 \%$ & $7 \%$ \\
\hline Magazines & $8 \%$ & $18 \%$ & $0 \%$ \\
\hline Branding & $8 \%$ & $18 \%$ & $0 \%$ \\
\hline Newsletters & $4 \%$ & $0 \%$ & $7 \%$ \\
\hline Guest Info folder & $4 \%$ & $9 \%$ & $0 \%$ \\
\hline Public Communications & $4 \%$ & $9 \%$ & $0 \%$ \\
\hline
\end{tabular}

* The number of responses does not add to 100\% because respondents provided more than 1 answer in many cases.

\section{Discussion of findings}

The questionnaire provided respondents with several opportunities to indicate whether they implement $\mathrm{CSR} /$ responsible tourism. From their responses it seems that there are very few that do not implement at least some form of CSR/responsible tourism, though the degree to which they implement it varies. Members on average implement more responsible tourism guideline elements than nonmembers. However, this is based purely on the individual's perceptions and only in the case of member hotels has the implementation of CSR/responsible tourism practices been independently verified.

Additionally we have seen that respondents' reasons for implementing the various responsible tourism guidelines in their business are largely related to their understanding of CSR. The most common understanding of CSR among respondents includes a responsibility to the community within which they operate their business, protecting the environment and ensuring the future sustainability of the industry, which is consistent with the generally accepted views on CSR (e.g. Van Marrewijk (2003); Garriga \& Melé's (2004); Kotler \& Lee (2005)). Most of respondents state that implementing the guidelines improves relations with the community (Van Marrewijk's societal approach (2003)) and protects the environment. It would appear, though, that there is less confusion among members than among non-members, as they have selected on average fewer descriptions of CSR. An alternative explanation is that due to the vague description of the terms, non-members tend to have a broader understanding of the term than that of members who appear to be quite precise in their understanding of each term. This latter explanation appears to be borne out by the data when one considers that nonmembers tend to have higher agreement than members, particularly in the lower part of the table.

On the issue of government policy or membership of tourism bodies as drivers of CSR/responsible tourism practices, only one respondent indicated that the reason for not reporting their responsible tourism policy was because it is not required by law and would indicate that this is not a significant motivating factor. In South Africa, members of FTTSA and Heritage represent $0,35 \%$ of all hotels and one could therefore conclude that responding hotels do not participate in CSR/responsible tourism initiatives because these initiatives are voluntary. Interestingly most responding hotels without a responsible tourism policy and provided a reason for not including such a policy in marketing and/or communications indicated that they haven't thought about it. Of these, more than $70 \%$ were not aware of DEAT's responsible tourism guidelines. This could provide another reason for hotels not participating in responsible tourism 
initiatives, i.e. that they are not aware of responsible tourism and therefore do not participate. A number of respondents indicated (often included in the e-mail accompanying the completed questionnaire) that the process of completing the questionnaire alerted them to various practices that they could implement. This emphasises the lack of awareness about responsible tourism in the industry.

When one compares the views of members about strategic issues to those of non-members, members implement on average more of the strategic responsible tourism guidelines, such as setting targets and objectives for being responsible, than non-members, which could imply that more members than non-members treat responsible tourism as a strategic issue in their business and explains their membership of these bodies. Additionally we found that significantly more non-members than members used brochures as a means to advertise their responsible tourism policy, and more members than non-members use advertisements in the press. This may be an indication that although non-members understand the value of including CSR/responsible tourism in their marketing material, that they do not see the value in belonging to a membership organisation such as FTTSA or Heritage. It should be emphasised, however, that the information included in a website and/or brochures is generally provided by the establishment and not independently verified, though in the case of advertising a complaint can be laid with the advertising complaints commission for misleading advertising should claims not be authentic.

A potential limitation to our study is that the relatively low percentage of responsible tourism guideline elements implemented by responding hotels could indicate that they do not meet the strict criteria of the membership organisations, and therefore do not belong to these organisations. This could be another reason for them not participating in responsible tourism initiatives. However, one has to acknowledge that the responsible tourism initiatives' criteria do not necessarily follow the DEAT responsible tourism guidelines and might exclude some guidelines and include other criteria.

Another limiting factor to our findings could be the relatively small proportion of respondents indicating that the reasons for implementing the various responsible tourism guideline elements in their business are because of influence of guests or tour operators - in other words, their clients and highlights the fact that the findings from the Tearfund research (Gordon, 2001) are not yet a pressing reality among South African hotels, although it is filtering through.

The sample of responding hotels represents $6 \%$ of the entire population of hotels in South Africa and approximately 10\% of formal hotels (which refer mainly to graded properties). One would be hesitant to generalise the findings of this study to the entire industry as a result of the wide scope of the industry, which includes not only registered hotels but bed and breakfast establishments and other similar enterprises. However, responding hotels represent a wide range of hotels in terms of size (from 6 to 318 rooms), the average number of rooms of responding hotels (67) is relatively close to the national average (60) (Grant
Thornton, 2004) and the geographical spread of responding hotels across South Africa correlate strongly to the geographical spread of hotels in the TGCSA database

It is recommended that a follow-up study be conducted with a larger sample to gain a deeper understanding of the various reasons mentioned above, as well as an understanding about the actual implementation of such practices. Such a study should include both quantitative and qualitative research. The study should further be extended to understand the distinctions in the application of CSR/responsible tourism among different types of establishments.

\section{Conclusions}

We have shown that there are material differences in the approach to responsible tourism between members of tourism associations and non-members. Member associations have a clearer understanding and conceptualisation of the term, they are more likely to implement responsible tourism measures and they understand the business rationale thereof, such as marketing advantages and the ability to differentiate one's business. The publication of guidelines by the DEAT did not have a material influence on the adoption of responsible tourism elements on non-members and it is unlikely that the South African government is in a position to legislate in this regard. Such legislation could have negative consequences for a strategic industry that is largely driven by small and medium entrepreneurial firms that would struggle with compliance in any event. The findings further suggest that the most effective way to increase the adoption of responsible tourism practices would be to support the responsible tourism associations to become representative of the industry and to allow the industry to regulate itself. If responsible tourism organisations do not acknowledge the reasons for hotels not participating in their initiatives they will not be able to increase their membership. It would appear that smaller hotels currently do not see the benefit in belonging to a responsible tourism membership organisation, or they do not meet the strict criteria of these organisations. Significantly smaller hotels do not offer the same level of service as the larger hotels and have smaller revenues which may be a contributing factor to implementing responsible tourism initiatives as responsible tourism is not seen by non-members as providing a business advantage.

With the increasing importance of responsible purchasing behaviours in major foreign markets such as the UK (Gordon, 2001), one would expect that hotels with a predominantly foreign customer base would be more inclined to implement responsible tourism practices at the insistence of their clients than hotels with a predominantly domestic customer base. Though there are not as many hotels in South Africa representing international hotel chains, an attempt should be made to understand the difference in implementing CSR/responsible tourism practices between hotels with an international affiliation and South African hotels. 
In conclusion, while it appears that the level of implementation of CSR/responsible tourism practices by hotels in South Africa is quite high, this does not translate into participation in responsible tourism initiatives, and additional research is required to fully understand this phenomenon among hotels in the South African hotel industry.

\section{References}

Ashley, C. \& Haysom, G. 2005. From philanthropy to a different way of doing business: Strategies and challenges in integrating pro-poor approaches into tourism business.' Paper presented in Pretoria, October 2004 at the ATLAS Africa Conference. Submitted as a paper, January 2005.

Ashley, C., Roe, D. \& Goodwin, H. 2001. Pro-poor tourism strategies: Making tourism work for the poor. Nottingham: The Russel Press.

Bac, L. 2005. Personal communication. Grant Thornton Tourism, Hospitality and Leisure Consultancy Director and FTTSA Selection Panel member, 14 September 2005.

Birch, D. \& Littlewood, G. 2004. 'Corporate citizenship: Some perspectives from Australian CEOs', Journal of Corporate Citizenship, 16: 61-69.

Bowes, B. \& Pennington, S. (Eds.). 2005. Miracles that are changing a nation. Johannesburg: South Africa - The Good News (Pty) Ltd.

Canniffe, M. 2005. 'Corporate social responsibility', Accountancy Ireland, 37(1): 6-9.

Carroll, A. B. 1979. 'A three-dimensional conceptual model of corporate performance', Academy of Management Review, 4(4): 497-505. (Cited in Garriga \& Mele, 2004.)

City Lodge. 2004. Annual Report. [online] URL: www.citylodge.co.za. Accessed 23/3/2005.

De Cleene, S. \& Sonnenburg, D. 2004. Socially responsible investment in South Africa. $2^{\text {nd }}$ Edition. Johannesburg: African Institute of Corporate Citizenship.

Department of Environmental Affairs \& Tourism (DEAT). 1996. White Paper on the Development and Promotion of Tourism in South Africa. Pretoria: Government Printer.

Department of Environmental Affairs \& Tourism (DEAT). 2003. Responsible tourism handbook. Pretoria: Government Printer.

Fair Trade in Tourism South Africa (FTTSA). 2005a. About us. [online] URL: http://www.fairtourismsa.org.za/aboutus/index html.

Accessed 13/9/2005.

Fair Trade in Tourism South Africa (FTTSA). 2005b. Fair trade. [online]

URL:http://www fairtourismsa.org.za/fairtrade/index.html.

Accessed 13/9/05.
Federated Hospitality Association of South Africa (Fedhasa). 2005. Imvelo Awards brochure. [online] URL: http://www fedhasa.co.za/imvelo/imvelo_brochure.pdf. Accessed 14/9/2005.

Freeman, R. E. 1984. Strategic management: A stakeholder approach. Boston: Pitman. (Cited in Garriga \& Mele, 2004 and Van Marrewijk, 2003).

Friedman, M. 1970. 'The social responsibility of business is to increase its profits', New York Times Magazine, September 13th, p.p. 32-33, 122, 126. (Cited in Garriga \& Mele, 2004).

Garriga, E. \& Melé, D. 2004. 'Corporate social responsibility theories: Mapping the territory’, Journal of Business Ethics. 53:51-71.

Global Compact. 2005a. 'What is the Global Compact?' [online] URL:

http://www.unglobalcompact.org/content/AboutTheGC/Ove rview_About htm. Accessed 04/09/2005.

Global Compact. 2005c. 'Company list'. [online] URL: http://www.unglobalcompact.org/irj/servlet/prt/portal/prtthe me/UN/prteventname/ Accessed 04/09/2005.

Gordon, G. 2001. (Ed.). Tourism: Putting ethics into practice. Dublin: Tearfund.

Grant Thornton. 2004. Ethekwini (Durban) hotel development strategy. Johannesburg: Grant Thornton.

Grant Thornton. 2005. Media presentation, 21 June 2005, Johannesburg. (Based on research conducted during 2002).

Henderson, D. 2005. The role of business in the world of today,' Journal of Corporate Citizenship, Spring, 17: 30-32.

Heritage Responsible Travel \& Accommodation Guide. 2005. 'Heritage environmental Ratings programme'. [online] URL: http://www.heritagesa.co.za/

Johannesburg Stock Exchange (JSE). 2005b. 'JSE companies listing'. [online] URL: www.jse.co.za. Accessed 6/9/2005.

Johannesburg Stock Exchange (JSE). 2005a. 'JSE SRI Index constituents’. [online] URL: www.jse.co.za. Accessed 6/9/2005.

Kotler, P. \& Lee, N. 2005. Corporate social responsibility: Doing the most good for your company and your cause. Hoboken, New Jersey: John Wiley \& Sons, Inc. USA.

Lashinger, K. 2004. 'Corporate social responsibility - the business of business', Finance Week, 27 October 2004: 70.

Locke, R. 2003. 'Note on corporate citizenship in a global economy'. Boston. Sloan School of Management and Department of Political Science, MIT. [online] URL: http://mitsloan.mit.edu/50th/pdf/corpcitizenship.pdf Accessed 13/9/2005. 
Logsdon, J.M. \& Wood, D.J. 2002. 'Business citizenship: From domestic to global level of analysis', Business Ethics Quarterly, 12(2):155-187.

McManus, G. 2005. Personal communication. Managing Director, Heritage Environmental Rating Programme, interviewed 26 August 2005.

Protea Hotels. 2005. 'Listing of South African hotels'. [online] URL: www.proteahotels.co.za. Accessed between 5/9/2005 and 20/9/2005.

Rockey, V. (Ed.). 2001. The CSI handbook. $4^{\text {th }}$ Edition. Cape Town: Trialogue.

Southern Sun Hotels. 2002. 'Corporate citizenship and sustainability report'. [online] URL: www.southernsun.com. Accessed 23/8/2005.

Sun International. 2003. 'Annual Report'. [online] URL: www.sunint.co.za. Accessed 23/9/2005.

The Don Group. 2005. 'Listing of hotels'. [online] URL: www.don.co.za. Accessed between 5/9/2005 and 20/9/2005.

Tourism Grading Council of South Africa (TGCSA). 2002. 'All you need to know about grading'. [online] URL: www.tourismgrading.co.za. Accessed 5/9/2005.

Tourism Grading Council of South Africa (TGCSA). 2005. 'Listing of graded hotels by province'. [online] URL: www.tourismgrading.co.za. Accessed between 5/9/2005 and $7 / 11 / 2005$.

Tourism KwaZulu-Natal (TKZN). 2002. 'Database of hotels'. Accessed from Ethekwini (Durban) Hotel Development Strategy, (Grant Thornton, 2004).

Tshwane Tourism Plan. 2005. 'Accommodation establishments database’. Johannesburg: Grant Thornton.

Valor, C. 2005. 'Corporate social responsibility and corporate citizenship: Towards corporate accountability’, Business and Society Review 110(2):191-212.

Van Marrewijk, M. 2003. 'Concepts and definitions of CSR and corporate sustainability: Between agency and communion', Journal of Business Ethics. 44: 95-105.

Votaw, D \& Sethi, S.P. 1973. The corporate dilemma: Traditional values versus contemporary problems. New York. Prentice Hall. Cited in Van Marrewijk, 2003.

World Travel and Tourism Council (WTTC), International Federation of Tour Operators (IFTO), International Hotel and Restaurant Association (IH\&RA), International Council for Cruise Liners (ICCL) and United Nations Environment Programme (UNEP). 2002. Industry as a partner for sustainable development. United Kingdom: The Beacon Press.
WTTC. 2005a. 'Tourism for Tomorrow Awards'. [online] URL: www.wttc.org. Accessed between 5/9/2005 and $7 / 11 / 2005$.

WTTC. 2005b. 'The 2005 travel and tourism economic research'. [onlinr] URL:www.wttc.org. Accessed between 5/9/2005 and 7/11/2005.

WTTC. 2006. 'TSA Research'. [online] URL: www.wttc.org. Accessed 20/02/2007. 
Appendix A: Questionnaire to Respondents

\begin{tabular}{|c|c|c|c|}
\hline $\mathrm{a}$ & Company Name & & \\
\hline $\mathrm{b}$ & Tel & & \\
\hline C & Fax & & \\
\hline $\mathrm{d}$ & E-mail & & \\
\hline e & Website & & \\
\hline $\mathrm{f}$ & Respondent Name & & \\
\hline g & Respondent Position & & \\
\hline $\mathrm{h}$ & Location (province) & & \\
\hline $\mathrm{i}$ & Number of Rooms & & \\
\hline $\mathrm{j}$ & Number of employees & & \\
\hline $\mathrm{k}$. & What type of operation do you have? & Full Service & Limited Service \\
\hline
\end{tabular}

\begin{tabular}{|l|l|l|l|l|l|l|}
\hline 1. & Type of legal entity & Public Company & $\begin{array}{c}\text { Private } \\
\text { Company }\end{array}$ & $\begin{array}{c}\text { Closed } \\
\text { Corporation }\end{array}$ & Partnership & Other \\
\hline
\end{tabular}

\begin{tabular}{|l|l|l|l|l|l|}
\hline 2. & \multicolumn{6}{|l|}{ What does the term 'Corporate Social Responsibility' mean to you? } \\
\hline A & triple bottom line & & h & ethical business practices \\
\hline B & philanthropic donations & & i & strategic business tool \\
\hline C & future sustainability of the industry & & j & $\begin{array}{l}\text { responsibility to the community within which } \\
\text { I operate my business }\end{array}$ & \\
\hline D & license to operate & & k & legal compliance & \\
\hline E & increased profitability & & $\mathbf{l}$ & marketing opportunity & \\
\hline F & increased cost of doing business & & $\mathbf{m}$ & feel-good factor & \\
\hline G & protecting the environment & & $\mathbf{n}$ & Other (Please specify) & \\
\hline
\end{tabular}

\section{\begin{tabular}{|l|l|l|l|}
\hline 3. & Do you believe your company implements corporate social responsibility? & Yes & No
\end{tabular}}

Responsible tourism is defined by the White Paper on Tourism Development in South Africa (1996) as "tourism that promotes responsibility to the environment through its sustainable use; responsibility to involve local communities in the tourism industry; responsibility for the safety and security of visitors and responsible government, employees, employers, unions and local communities”

\begin{tabular}{|l|l|l|l|l|l|l|}
\hline 4. & \multicolumn{2}{|l|}{ Does your company have a responsible tourism policy? } & Yes & No \\
\hline 4a. & \multicolumn{2}{|l|}{ If yes, do you include this in your marketing material and/or communications? } & Yes & No \\
\hline 4b. & \multicolumn{2}{|l|}{ If yes in 4a, where do you include it? } & & & \\
\hline i & Brochures & & iii & Website & Other (Please specify) & \\
\hline ii & Advertisements & & \\
\hline & \multicolumn{3}{|l|}{} & \\
\hline 4c. & If no in 4a, why not? & iii & Not required by law & \\
\hline i & Haven't thought about it & & \\
\hline
\end{tabular}




\begin{tabular}{|l|l|l|l|l|l|}
\hline ii & Don't believe it's important & & iv & Other (Please specify) & \\
\hline
\end{tabular}

\begin{tabular}{|l|l|c|c|}
\hline 5. & $\begin{array}{l}\text { Are you aware of the Department of Environmental Affairs and Tourism's } \\
\text { Responsible Tourism Handbook? }\end{array}$ & Yes & No \\
\hline 5a. & Do you implement any of the guidelines in your business? & Yes & No \\
\hline
\end{tabular}

5b. $\quad$ If yes, which of the following elements do you implement in your business?

\begin{tabular}{|l|l|c|}
\hline & (Please tick all that apply) & Tick \\
\hline A & Economic elements & \\
\hline A & Assess the economic impacts of your tourism activities &
\end{tabular}

\begin{tabular}{|l|l|l|}
\hline A & Assess the economic impacts of your tourism activities & \\
\hline B & Maximise local economic benefits by increasing linkages and reducing leakages & \\
\hline C & Ensure communities are involved in and benefit from tourism & \\
\hline D & Employ responsible and transparent processes when employing staff and pay fair wages & \\
\hline E & Assist with local marketing and product development & \\
\hline F & Promote equitable business and pay fair prices. & \\
\hline B & Social Elements &
\end{tabular}

\begin{tabular}{|l|l|l|}
\hline A & Involve local communities in planning and decision making & \\
\hline B & Assess social impacts of your tourism activities & \\
\hline C & Respect social and cultul & \\
\hline
\end{tabular}

\begin{tabular}{|l|l|l|}
\hline C & Respect social and cultural diversity & \\
\hline D & Be sensitive to the host cultire & \\
\hline
\end{tabular}

\begin{tabular}{|l|l|l|}
\hline D & Be sensitive to the host culture & \\
\hline C & Environmental Elements & \\
\hline
\end{tabular}

\begin{tabular}{|c|c|}
\hline C & Environmental Elements \\
\hline A & Reduce environmental impacts when developing tourism \\
\hline B & Use natural resources sustainably. \\
\hline $\mathrm{C}$ & Maintain biodiversity. \\
\hline $\mathbf{D}$ & Motivating Guests to be Responsible \\
\hline A & Encourage guests to spend money in the local community \\
\hline B & Provide an opportunity for guests to contribute to a local charity / funding initiative \\
\hline $\mathrm{C}$ & Inform guests on how to interact with the local community \\
\hline $\mathrm{D}$ & Encourage guests to conserve water and energy by providing information in their rooms \\
\hline $\mathrm{E}$ & Provide an opportunity for guests to contribute to local conservation programmes \\
\hline $\mathrm{F}$ & Provide separate bins in guest rooms for waste \\
\hline $\mathbf{E}$ & General \\
\hline A & Set targets and objectives for being responsible \\
\hline B & Use benchmarks to measure and report on progress \\
\hline $\mathrm{C}$ & Work with trade associations, local people and government to achieve objectives \\
\hline $\mathrm{D}$ & Use responsible tourism as part of your marketing strategy \\
\hline $\mathrm{E}$ & Show progress to staff and clients \\
\hline
\end{tabular}

\begin{tabular}{|l|l|l|l|l|l|l|}
\hline 6. & \multicolumn{6}{|l}{ Why do you implement the elements in Question 5? (Please tick all that apply) } \\
\hline a & It is important to me personally & & h & Is strategically important to my business & \\
\hline b & Is ethical / the right thing to do & & i & Required by law & \\
\hline c & Required by membership organisation & & j & Improves relationships with the community & \\
\hline
\end{tabular}




\begin{tabular}{|c|c|c|c|c|c|}
\hline & & & \multicolumn{2}{|c|}{ where I operate my business } & \\
\hline d & Saves costs & $\mathbf{k}$ & \multicolumn{2}{|c|}{ Because of the feel-good factor } & \\
\hline e & Influence from guests & $\mathbf{l}$ & \multicolumn{2}{|l|}{ Protects the environment } & \\
\hline f & Future sustainability of the industry & m & \multicolumn{2}{|c|}{ Influence from tour operators } & \\
\hline g & Able to charge a premium & $\mathbf{n}$ & \multicolumn{2}{|l|}{ Other (Please specify) } & \\
\hline 7. & \multicolumn{3}{|c|}{ Are you a member of Fair Trade in Tourism South Africa (FTTSA)? } & Yes & No \\
\hline 8. & \multicolumn{3}{|c|}{ Have you ever participated in the FEDHASA Imvelo Awards? } & Yes & No \\
\hline 8.a & If yes, in which category? & & & & \\
\hline 9. & \multicolumn{3}{|c|}{ Are you a member of the Heritage Environmental Ratings Programme? } & Yes & No \\
\hline
\end{tabular}

